Haya: The Saudi Journal of Life Sciences

Abbreviated Key Title: Haya Saudi J Life Sci

ISSN 2415-623X (Print) |ISSN 2415-6221 (Online)

Scholars Middle East Publishers, Dubai, United Arab Emirates

Journal homepage: https://saudijournals.com

Review Article

\title{
Sustainable Agricultural and Entomological Approaches Towards Immunity for Defense System in Insects
}

\author{
Muhammad Irfan Zafar ${ }^{1}$, Mazher Hussain Farooqi ${ }^{1 *}$, Sayyed Muhammad Muntizir Shah ${ }^{1}$, Bilal Ahmad ${ }^{1}$, Mukarram $^{2}$ \\ $\mathrm{Khan}^{2}$ \\ ${ }^{1}$ Department: Agriculture Entomology, University: University of Agriculture Faisalabad Pakistan \\ ${ }^{2}$ Department of Agriculture Extension, University College of Agriculture, Sargodha Pakistan
}

DOI: $10.36348 /$ sjls.2022.v07i01.002 $\quad$ | Received: 31.11.2021 | Accepted: 03.01.2022 | Published: 15.01 .2022

*Corresponding author: Mazher Hussain Farooqi

Department: Agriculture Entomology, University: University of Agriculture Faisalabad Pakistan

\section{Abstract}

Immunity in insects is the series of events by discretion of signal proteins as a part of memory cells. The most important role of defensive proteins and peptides in insects are against function, assigning immune responses distinctly to priming and basal. But insects are also a source of high quality protein, containing many essential amino acids required for human nutrition. One their host enters into the cells of targeting area, immediate onset of proteolytic cascades that causes the cleavage of protein molecules of the attacking organisms. Immune system of the insects enhances exhibit properties the of production of antibodies and phagocytic cells to clear microbes and damaged cells from an organism. The most different types of immunological responses arise as pathogens enter into the cells of insects and activate the machinery of metabolic pools. The main reason for genetic and biochemical evaluation lie behinds the diversity of natural ecosystem of insects. Sterile insect technique has been controlled for direct killing. It is used primarily to control or eradicate insect pests, usually crop pests or human and animal. Integrated pest management, the broad-based approach that integrates practices for economic control of pests that significantly improved the yields of agricultural crops.

Keywords: Immunity in insects, integrated pest management, pests, agricultural crop.

Copyright (C) 2022 The Author(s): This is an open-access article distributed under the terms of the Creative Commons Attribution 4.0 International License (CC BY-NC 4.0) which permits unrestricted use, distribution, and reproduction in any medium for non-commercial use provided the original author and source are credited.

\section{INTRODUCTION}

Animals have diverse immune system to protect themselves against variety of harmful pathogens. Among them, insects possess a robust immune system that act in systematic manner against releasing different types of hormones, peptides and other chemical compounds. These chemical compounds are main barriers to the attacking pathogens. The also sense a signal against a variety of other pathogenic microbes but potential mechanism remains unclear and needed to revaluation for boosting the immunity power of insects. The most important chemical compounds are anti-microbial peptides, phenoloxidase that are usually expressed and can act rapidly [1, 2, 6, 9].
The most important roles of defensive proteins and peptides in insects are against function, assigning immune responses distinctly to priming and basal immunity [1-3]. Escherichia coli also attack to the immune cells of caterpillars that rapidly respond to infection different types of hormones, peptides and other chemical compounds. Immune responses in many insects have been investigated in different experimental studies but mode of entry to the accurate orientation is necessary for the undiscovered molecular expressed proteins. But insects are also a source of high quality protein, containing many essential amino acids required for human nutrition. This response has been acting as virulent insect pathogen and can increase the growth of other pathogenic attacking organisms $[4,5]$. 
Table-1: Shows the different factors, management techniques affecting insects

\begin{tabular}{|l|l|l|l|}
\hline Insect & Function & Adaptation/Significance & Signficance \\
\hline $\begin{array}{l}\text { Symbiotic } \\
\text { relationship }\end{array}$ & $\begin{array}{l}\text { It can maintain the accurate } \\
\text { balance in the food chain }\end{array}$ & $\begin{array}{l}\text { These adaptations in different insects } \\
\text { proved helpful for survival in the } \\
\text { environment }\end{array}$ & {$[15]$} \\
\hline Insect Immunity & $\begin{array}{l}\text { Can trigger through signal } \\
\text { proteins in the form of } \\
\text { proteolytic cascades }\end{array}$ & $\begin{array}{l}\text { It leads to control of many infections in } \\
\text { insects }\end{array}$ & {$[11-14]$} \\
\hline $\begin{array}{l}\text { Sterile insect } \\
\text { technique }\end{array}$ & $\begin{array}{l}\text { Controlling the eradication of } \\
\text { pest species in order for } \\
\text { preventing measures. }\end{array}$ & $\begin{array}{l}\text { Preventing the useful species of insects } \\
\text { as they can provide benefits to the } \\
\text { human }\end{array}$ & {$[23-25]$} \\
\hline $\begin{array}{l}\text { vector-borne } \\
\text { pathogens }\end{array}$ & $\begin{array}{l}\text { major cause of destruction of } \\
\text { agricultural crops }\end{array}$ & $\begin{array}{l}\text { cause drastic changes in nutritional value } \\
\text { and poor agricultural yields }\end{array}$ & {$[26-28]$} \\
\hline
\end{tabular}

\section{Immunity based different Interactions in insects}

Insects have different types of defensive molecular expressed proteins to microorganisms. One their host enters into the cells of targeting area, immediate onset of proteolytic cascades that causes the cleavage of protein molecules of the attacking organisms. It can leads to increase the production of cytotoxic molecules are synthesized and loaded into the lytic granules during the first encounter of a naive cytotoxic precursors. It can promote the process of phagocytosis to kill the invading microorganisms. It can lead to express the variety of different guns presented on the surfaces of attacking microorganisms. Crucially, identification of different patterns can used as in genetics of Drosophila provides a unique opportunity to dissect the development and differentiation [6-8].

Due to the diverse nature of insects in the nature, it is important to assess the virulence of many of the pathogenic fungal and bacterial pathogens. It leads to control of many infections in insects caused by lethal and deadly viruses and the results of studies correlate with those obtained using mammals $[9,10]$. The most different types of immunological responses arise as pathogens enter into the cells of insects and activate the machinery of metabolic pools. One of the kinds of response is the transgenerational immune riming that is usually memory beneficial for the insects in protecting their body against variety of toxic proteins. The common and effective type of insect viruses is the baculoviruses, insect species worldwide. It also protect their offspring in order to transform the toxic genes and thus wide diversity of immunity exist in insects [11, 12].

Immunity in insects follows the processes of encapsulation that trigger the innate immunity responses through series of events by discretion of signal proteins as a part of memory cells. Insect wounding activation process can be trigger through signal proteins in the form of proteolytic cascades that causes the proteolysis and destruction of toxic proteins protein released by other pathogens. These results in haemolymph coagulation and melanization comminuted for humoral and cellular components for the different clotting factors. These series of events sometimes can cause inflammatory responses by causing the genetic proteins to coagulated for the formation of other targeted proteins of attacking pathogens $[13,14]$.

Sometimes, insects can establish the beneficial relationship by interacting with different types of herbivores. These can leads to formation of bidirectional flow of materials and nutrients in two ways throughout the defensive system of plant. Insects' also different strategies for self protection from parasites or predators. For many insects, a quick escape by running or flying is the primary mode of defense. It can maintain the accurate balance in the food chain through supplementation of essential amino acids for the insect's growth. Through symbiotic relapse, many of the insects have bee gained benefit by flowing the patterns of repellence as well as attraction of attacking organism or its natural enemy. These adaptations in different insects proved helpful for survival in the environment that they live in order to conserve the natural ecosystems $[15,16]$.

Genetic factors are involved for long-time coevolution for leads to discovery of new genes encoding for bioactive secondary metabolites. The main reason for genetic and biochemical evaluation lie behinds the diversity of natural ecosystem of insects. Through the interactions in physical and chemical ways, virulence factors mediating the interactions with the respective insect host [16-19]. Through the immune response as a result of invade host cells; resist innate immune defenses such as phagocytosis and complement has been studied wildly due to their large populations of insects. As insects exist everywhere, there is need to complementary system of immune system for marinating the immune balance in the insect body. In this way, sometimes, overexpression of complementary system leads to abnormities in immune system. While on the other hand, poorexpression of complementary system causes immune system failure to perform its 
Muhammad Irfan Zafar et al., Haya Saudi J Life Sci, Jan, 2022; 7(1): 9-12

function than normal mode. Immune system of the insects enhances exhibit properties the of production of antibodies and phagocytic cells to clear microbes and damaged cells from an organism. In this way, they can survive any environment through releasing chemicals and pheromones [20-22].

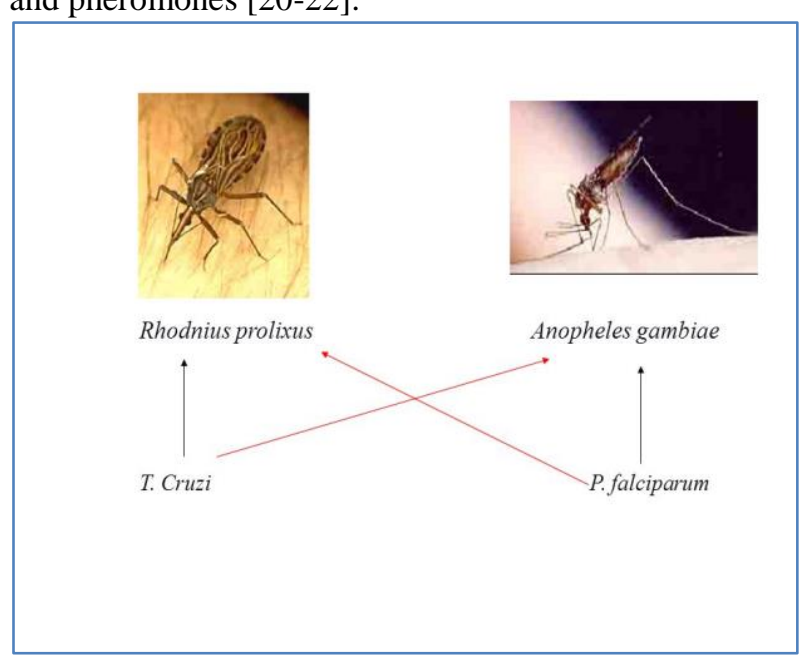

Fig-1: Shows the Immunity and Host-Microbe Interactions in Insects

There are many factors involved in secretion of hormones and pheromones in insects against the invading microorganisms or any pathogens. Severe attack of microorganisms or any pathogens in the insects body leads to increase the production of antibodies that are potent against invading pathogens. While on the other hand, abnormal response by immune system of insects to poor attack of microorganisms or any pathogens in the insect's body leads to decrease the production of antibodies. Among the bacterial species that are able to cause disease in insects some of them are opportunistic, such as Bacillus thuringiensis. Different types of variety of toxins, and the development of strategies to evade the host immune system are required for the success of the infection[1,17,19, 20,21,22]. It can make adaptive mechanism in insects that can increased the survival chances by making a symbiotic relationship among different groups animals. Activities of insects many insects, especially beetles, are scavengers, feeding on dead animals and fallen trees, thereby recycling nutrients back into the soil. In this way, they are used for industrial purposes and agricultural interests.

Sterile insect technique is widely used for controlling the eradication of pest species in order for preventing measures. Through this technique, lots of species of tephritid fruit flies have been controlled for direct killing. It is used primarily to control or eradicate insect pests, usually crop pests or human and animal pests. It is also useful for integrated pest management where sometime, harmful insects can be categorized and distinguish on the basis of certain characteristics. It leads to evolutionary step in preventing the useful species of insects as they can provide benefits to the human [23-25].

Uncontrolled attack of vector-borne pathogens from insects group are major cause of destruction of agricultural crops due to low yield and poor quality products as compared to those achieving high quality yields. They can cause drastic changes in nutritional value, volatile profiles, and defenses, which ultimately leads to poor relationship between pants and insects. The main purpose is to promote the using of insect symbionts with key nutrients that can be controlled the attack of number of herbivores or on plant-associated microorganisms. Integrated pest management, the broad-based approach that integrates practices for economic control of pests that significantly improved the yields of agricultural crops by establishing the ecofriendly and provides number of benefits to the human population [26-30].

\section{CONCLUSION}

Due to larger diversity of insects and habitat nature, immune responses triggers against the pathogenic bacteria and differentiated them by releasing the different types of chemicals peptides, and eliminating undesirable, sensitive bacteria. This review helpful to understand the immunity and immune responses involved in cellular and molecular expression. Many of the new genes that are involved in insects immunological behavior can controlled the attack of other pathogens in targeting toxic proteins.

\section{REFERENCES}

1. Ramond, E., Dudzic, J. P., \& Lemaitre, B. (2020). Comparative RNA-Seq analyses of Drosophila plasmatocytes reveal gene specific signatures in response to clean injury and septic injury. PloS one, 15(6), e0235294.

2. Prakash, A., \& Khan, I. (2022). Why do insects evolve immune priming? A search for crossroads. Developmental \& Comparative Immunology, 126, 104246.

3. González-Santoyo, I., \& Córdoba-Aguilar, A. (2012). Phenoloxidase: a key component of the insect immune system. Entomologia Experimentalis et Applicata, 142(1), 1-16.

4. Eleftherianos, I., Marokhazi, J., Millichap, P. J., Hodgkinson, A. J., Sriboonlert, A., \& Reynolds, S. E. (2006). Prior infection of Manduca sexta with non-pathogenic Escherichia coli elicits immunity to pathogenic Photorhabdus luminescens: roles of immune-related proteins shown by RNA interference. Insect biochemistry and molecular biology, 36(6), 517-525.

5. Cooper, D., \& Eleftherianos, I. (2017). Memory and specificity in the insect immune system: current perspectives and future challenges. Frontiers in immunology, 8, 539. 
Muhammad Irfan Zafar et al., Haya Saudi J Life Sci, Jan, 2022; 7(1): 9-12

6. Hoffmann, J. A., Reichhart, J. M., \& Hetru, C. (1996). Innate immunity in higher insects. Current opinion in immunology, 8(1), 8-13.

7. Hoffmann, J. A. (1995). Innate immunity of insects. Current opinion in immunology, 7(1), 4-10.

8. Hoffmann, J., Akira, S., \& Hoffmann, J. (2013). Innate immunity editorial overview. Curr Opin Immunol [Internet], 25(1), 1-3.

9. Brennan, M., Thomas, D. Y., Whiteway, M., \& Kavanagh, K. (2002). Correlation between virulence of Candida albicans mutants in mice and Galleria mellonella larvae. FEMS Immunology \& Medical Microbiology, 34(2), 153-157.

10. Jander, G., Rahme, L. G., \& Ausubel, F. M. (2000). Positive correlation between virulence of Pseudomonas aeruginosa mutants in mice and insects. Journal of bacteriology, 182(13), 38433845.

11. Moret, Y. (2006). 'Trans-generational immune priming': specific enhancement of the antimicrobial immune response in the mealworm beetle, Tenebrio molitor. Proceedings of the Royal Society B: Biological Sciences, 273(1592), 13991405.

12. Knorr, E., Schmidtberg, H., Arslan, D., Bingsohn, L., \& Vilcinskas, A. (2015). Translocation of bacteria from the gut to the eggs triggers maternal transgenerational immune priming in Tribolium castaneum. Biology letters, 11(12), 20150885.

13. Hultmark, D. (1993). Immune reactions in Drosophila and other insects: a model for innate immunity. Trends in Genetics, 9(5), 178-183.

14. Wright, T. R. (1987). The genetics of biogenic amine metabolism, sclerotization, and melanization in Drosophila melanogaster. Advances in genetics, 24, 127-222.

15. Noman, A., Aqeel, M., Qasim, M., Haider, I., \& Lou, Y. (2020). Plant-insect-microbe interaction: A love triangle between enemies in ecosystem. Science of The Total Environment, 699, 134181.

16. Spiteller, P. (2015). Nat. Prod. Rep, 32, 971-993. doi:10.1039/C4NP00166D

17. Isaka, M., Kittakoop, P., \& Thebtaranonth, Y. (2003). Secondary metabolites of clavicipitalean fungi. In Clavicipitalean Fungi (pp. 342-383). CRC Press.

18. White, J. F., Bacon, C. W., Hywel-Jones, N. L., Spatafora, J. W., Eds., Mycology, 19; CRC Press: New York, 2003; 355-397

19. Isaka, M., Kittakoop, P., Kirtikara, K., HywelJones, N. L., \& Thebtaranonth, Y. (2005). Bioactive substances from insect pathogenic fungi. Accounts of Chemical Research,38(10), 813-823.

20. Vallet-Gely, I., Lemaitre, B., \& Boccard, F. (2008). Bacterial strategies to overcome insect defences. Nature Reviews Microbiology, 6(4), 302313.

21. Kupferschmied, P., Maurhofer, M., \& Keel, C. (2013). Promise for plant pest control: rootassociated pseudomonads with insecticidal activities. Frontiers in plant science, 4, 287.

22. Aujoulat, F., Roger, F., Bourdier, A., Lotthé, A., Lamy, B., Marchandin, H., \& Jumas-Bilak, E. (2012). From environment to man: genome evolution and adaptation of human opportunistic bacterial pathogens. Genes, 3(2), 191-232.

23. Hendrichs, J., Vreysen, M. J. B., Enkerlin, W. R., \& Cayol, J. P. (2021). Strategic options in using sterile insects for area-wide integrated pest management. In Sterile Insect Technique (pp. 841884). CRC Press.

24. Barnes, B. N., Hofmeyr, J. H., Groenewald, S., Conlong, D. E., \& Wohlfarter, M. (2015). The sterile insect technique in agricultural crops in South Africa: a metamorphosis.... but will it fly?. African Entomology, 23(1), 1-18.

25. Enkerlin, W., Gutiérrez-Ruelas, J. M., Cortes, A. V., Roldan, E. C., Midgarden, D., Lira, E., ... \& Arriaga, F. J. T. (2015). Area freedom in Mexico from Mediterranean fruit fly (Diptera: Tephritidae): a review of over 30 years of a successful containment program using an integrated area-wide SIT approach. Florida entomologist, 665-681.

26. Baig, F., Farnier, K., Piper, A. M., Speight, R., \& Cunningham, J. P. (2020). Yeasts Influence Host Selection and Larval Fitness in Two Frugivorous Carpophilus Beetle Species. Journal of chemical ecology, 46(8).

27. Giron, D., Dedeine, F., Dubreuil, G., Huguet, E., Mouton, L., Outreman, Y., ... \& Simon, J. C. (2017). Influence of microbial symbionts on plantinsect interactions. Advances in botanical research, 81, 225-257.

28. Mergaert, P. (2018). Role of antimicrobial peptides in controlling symbiotic bacterial populations. Natural product reports, 35(4), 336356.

29. Mikonranta, L., Mappes, J., Kaukoniitty, M., \& Freitak, D. (2014). Insect immunity: oral exposure to a bacterial pathogen elicits free radical response and protects from a recurring infection. Frontiers in zoology, 11(1), 1-7.

30. Miller, W. J. (2013). Bugs in transition: the dynamic world of Wolbachia in insects. PLoS genetics, 9(12), e1004069. 